Article

\title{
Motivations and Intended Outcomes in Local Governments' Declarations of Climate Emergency
}

\author{
Xira Ruiz-Campillo ${ }^{1, *}$, Vanesa Castán Broto ${ }^{2}$ and Linda Westman ${ }^{2}$ \\ ${ }^{1}$ Department of International Relations and Global History, Complutense University of Madrid, 28223 Madrid, Spain; \\ E-Mail: xiraruiz@ucm.es \\ 2 Urban Institute, Interdisciplinary Centre for the Social Sciences, University of Sheffield, Sheffield, S14PD, UK; \\ E-Mails: v.castanbroto@sheffield.ac.uk (V.C.B.), I.westman@sheffield.ac.uk (L.W.) \\ * Corresponding author
}

Submitted: 17 October 2020 | Accepted: 23 December 2020 | Published: 28 April 2021

\begin{abstract}
Near 1,500 governments worldwide, including over 1,000 local governments, have declared a climate emergency. Such declarations constitute a response to the growing visibility of social movements in international politics as well as the growing role of cities in climate governance. Framing climate change as an emergency, however, can bring difficulties in both the identification of the most appropriate measures to adopt and the effectiveness of those measures in the long run. We use textual analysis to examine the motivations and intended outcomes of 300 declarations endorsed by local governments. The analysis demonstrates that political positioning, previous experience of environmental action within local government, and pressure from civil society are the most common motivations for declaring a climate emergency at the local level. The declarations constitute symbolic gestures highlighting the urgency of the climate challenge, but they do not translate into radically different responses to the climate change challenge. The most commonly intended impacts are increasing citizens' awareness of climate change and establishing mechanisms to influence future planning and infrastructure decisions. However, the declarations are adopted to emphasize the increasing role cities are taking on, situating local governments as crucial agents bridging global and local action agendas.
\end{abstract}

\section{Keywords}

cities; climate change; climate emergency; emergency declarations; local governments; performative acts; politics

Issue

This article is part of the issue "Is There a New Climate Politics? Emergency, Engagement and Justice" edited by Anna R. Davies (Trinity College Dublin, Ireland), Stephan Hügel (Trinity College Dublin, Ireland) and Vanesa Castán Broto (University of Sheffield, UK).

(C) 2021 by the authors; licensee Cogitatio (Lisbon, Portugal). This article is licensed under a Creative Commons Attribution 4.0 International License (CC BY).

\section{Introduction}

An emergency is a serious and unexpected incident that requires immediate action. In its 2014 report, the Intergovernmental Panel on Climate Change (IPCC; IPCC, 2014) showed with high confidence that climate change will increase the risks from heat stress, extreme precipitation, inland and coastal flooding, landslides, and water scarcity in urban areas. Multiple strands of multidisciplinary research have documented the impacts of climate change, for example, on human health and well- being (Committee OTEOC, 2011; Diaz, 2004; Goodwin et al., 2017), on economies and livelihoods (Kahn et al., 2019; Reid, Linda, Stage, \& Macgregor, 2008; Stern, 2007; Wade \& Jennings, 2016), on agriculture (Dinar et al., 1998; Maharjan \& Joshi, 2013; Wang et al., 2009), and biodiversity (Brown et al., 2015; Jaeschke, Bittner, Jentsch, \& Beierkuhnlein, 2014; Madhusoodhanan, Sreeja, \& Eldho, 2016). Based on the data on emergency events of the Centre for Research on the Epidemiology of Disasters, 7,804 natural disasters occurred between 1980 and 1999 compared to 13,388 disasters between 2000 and 2019 . 
Many institutions, from the United Nations Environment Programme to the European Parliament, characterize this situation as a climate emergency.

Cities have been central to emergency discourses. Darebin (Australia) was the first city in the world to declare a climate emergency on December 5, 2016. Three years later, more than 1,500 climate emergency declarations had been passed by governments and jurisdictions in 29 countries, covering a population of more than 820 million (Cedamia, 2020). Approximately 1,000 of these correspond to local governments, of which most are concentrated in high-income countries, except for three declarations in the Philippines and one in Brazil (Figure 1; see also Supplementary File 1).

The peak in the adoption of declarations occurred after mid-2019, with more than 900 local declarations adopted in the space of only a few months. This peak occurred at the time of the release of the Global Warming of $1.5^{\circ} \mathrm{C}$ IPCC report in October 2018, which coincided with a surge in internet searches for 'climate emergency' and 'climate crisis' (Thackeray et al., 2020). Local governments had adopted 1,000 declarations by April 2020 (Figure 2). This is, however, not a local phenomenon: Institutions at all levels of governance, including supranational authorities and businesses, have adopted climate emergency declarations. Moreover, in December 2020, the UN secretary-general, António Guterres, asked all governments to declare a state of climate emergency until the world has reached net-zero $\mathrm{CO}_{2}$ emissions (Harvey, 2020).
The term 'climate emergency' has been present in international climate politics for over two decades. Statements from the early United Nations Framework Convention on Climate Change Conference of Parties (the COPs) primarily urged technology transfers and finance to support transitions in low-income countries. However, the Fourth Assessment Report of the IPCC (from 2007) and Al Gore's documentary An Inconvenient Truth (from 2006) marked an inflexion point in the international discourse. In 2007, after a visit to Antarctica, former UN Secretary-General Ban Ki-Moon declared that climate change was an emergency that required emergency action ("UN chief makes Antarctica visit," 2007). A few months later, Spratt and Sutton (2008) published Climate Code Red: The Case for Emergency Action, which argued that declaring a state of emergency was a strategy for governments and other institutions to move away from 'business as usual' strategies to tackle climate change (Spratt \& Sutton, 2008). A network of grassroots climate groups in Australia adopted the term 'climate emergency' to demand emergency action (Cedamia, 2020). Simultaneously, emergency discourses proliferated in academic reports, policy documents, and the media (Wilson \& Orlove, 2019).

The declarations can be read as the culmination of social movements' efforts to raise the climate change profile in public policy. Climate emergency discourse brings together multiple constituencies, including established environmental movements, direct action groups (such as Extinction Rebellion), and a rapidly-growing

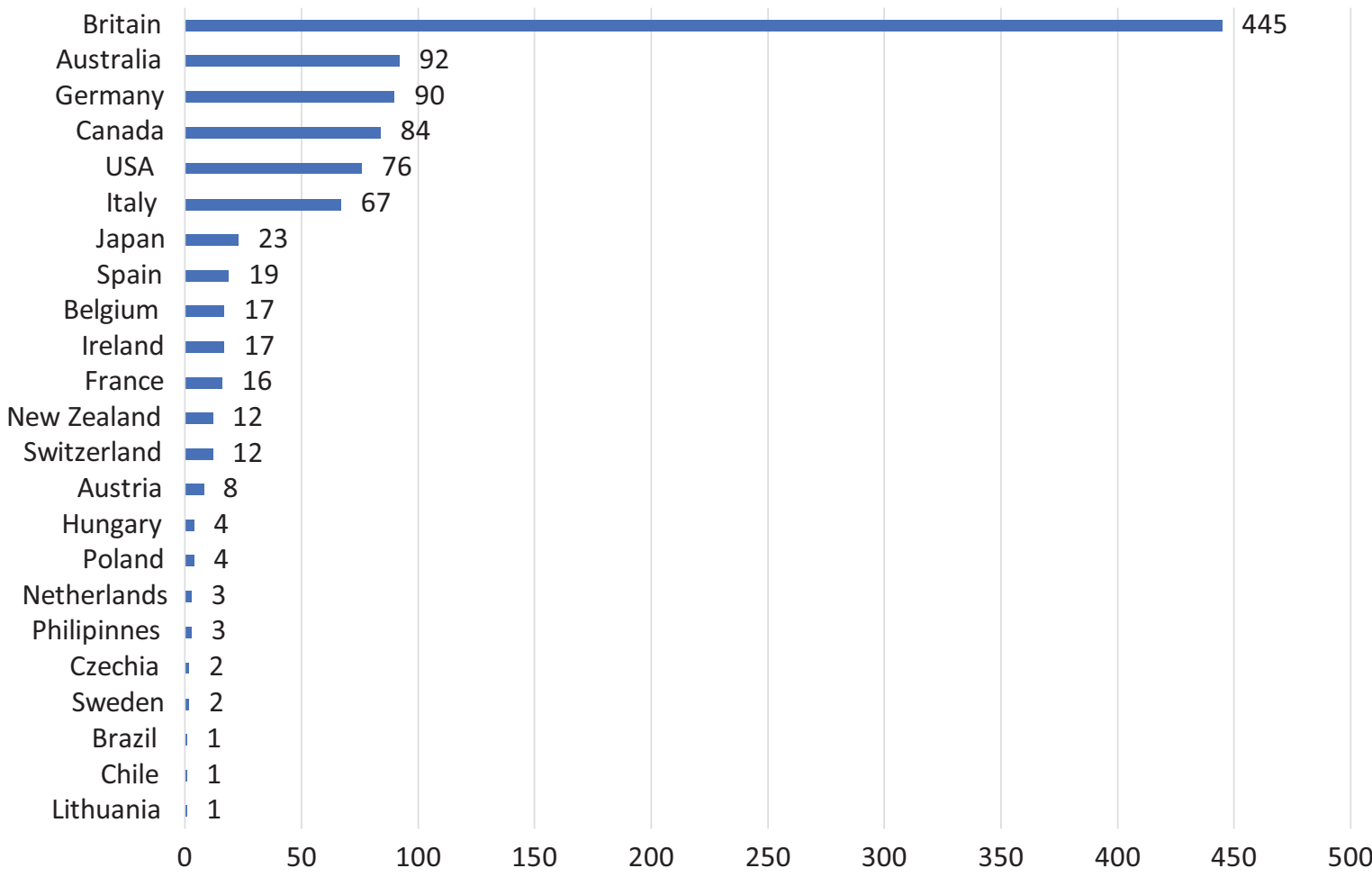

Figure 1. Declarations in local governments (by countries). Source: Authors' elaboration with information retrieved from Cedamia.org in April 2020. 


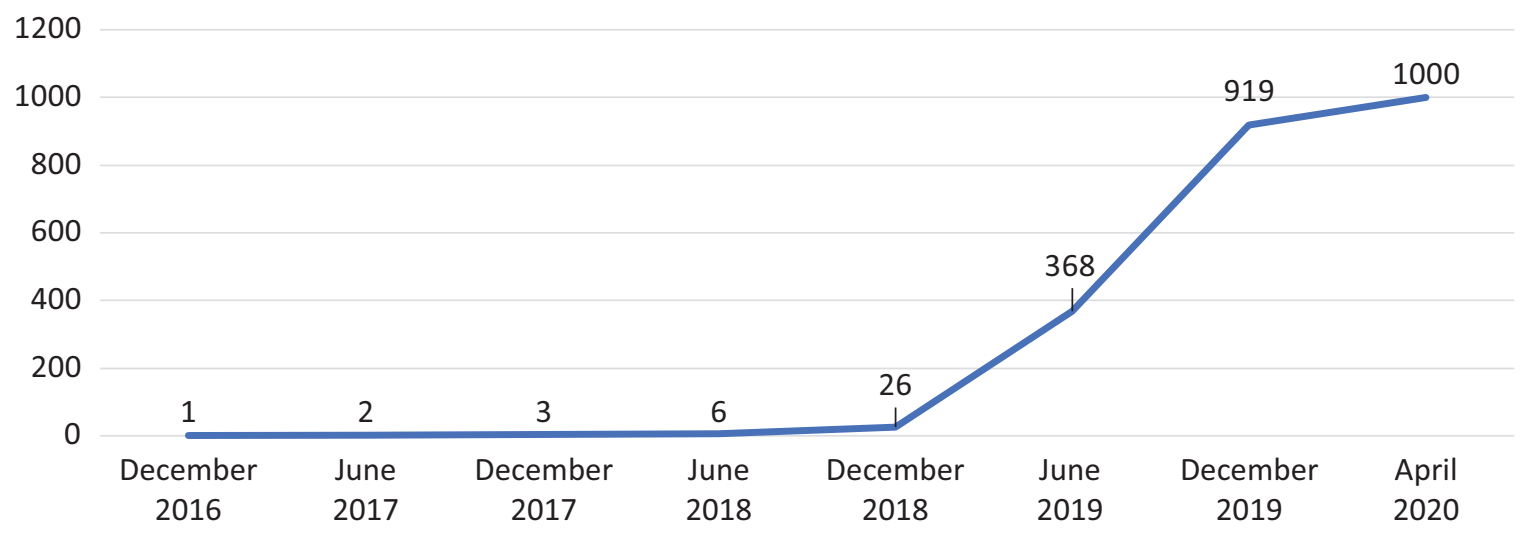

Figure 2. Evolution in the number of declarations adopted by local governments. Source: Authors' elaboration with information retrieved from Cedamia.org in April 2020.

international youth movement (Fridays for Future). These movements claim that current government action is insufficient to address climate change (UN Environment Programme, 2019).

This article aims to explore the scope of the climate emergency declarations, focusing on explicitly stated motivations and intended outcomes of local governments. The declarations emerge as a new putative mechanism to govern climate change in cities (Bulkeley \& Kern, 2006; Kern \& Alber, 2009). Following a literature review, our position is that emergency declarations mediate forms of performative power that influence climate governance at the local level. Our analysis involves a systematic examination of the motivations and intended outcomes of 300 declarations of climate emergency in local governments in 24 countries. The analysis of motivations suggests that the declarations constitute an instrument for local governments to position themselves in a global political landscape. However, the declarations also have performative power, as local governments commit to being held to account for their decisions. While the declarations may well fail to generate new forms of rapid, transformative action to tackle climate change, they do herald new political interactions to respond to climate change.

\section{Performative Acts and the Meaning of 'Emergency'}

The emergency discourse relates to the growing salience of an understanding of climate change as a security issue in academic and political debates. Climate change securitization became mainstream between 2007 and 2011 when it reached organizations such as the EU, the Organization for Security and Co-operation in Europe (OSCE), and the UN (Scott, 2012; Torres Camprubí, 2016). The framing of climate change as an existential issue, as a crisis or a disaster, is seen by some as a move to influence the way climate change is debated and understood, arguing that the rhetoric of emergency helps to bring climate change out of the ordinary and signals the need for quick action (Warner \& Boas, 2017). While some fear that this securitisation shift may jeopardize decades of humanitarian work and human development programs (Thomas \& Warner, 2019), others see it as an opportunity to regulate climate change through legislation, to make national governments more likely to assume their responsibilities (Giles Carnero, 2016), or to turn the military into a more valuable tool by involving them in the response to climate change (Matthew, 2000).

Oels (2012) has described three different schools of thought that analyse the framing of climate change as a security threat: the Copenhagen School, the human security perspective, and the Paris School (Oels, 2012). The Copenhagen School is concerned with the extent to which securitization of climate change as an existential threat may legitimise the implementation of mitigation and adaptation action via undemocratic procedures (Scott, 2012). The human security school links climate change to the vulnerability of local places and social groups, shifting the focus from state security to personal safety and sustainable development (Barnett \& Adger, 2007). Finally, the Paris School argues for moving the focus away from the securitisation of climate change to the climatization of the security industry, as security professionals and institutions become increasingly engaged in climate action and debate (Oels, 2012; see also Jayaram, 2020).

Despite its widespread use, what the term 'emergency' refers to in the phrase 'climate emergency' is unclear. There are different meanings of the concept of emergency (Anderson \& Adey, 2012). For this article, we use a conventional definition of 'emergency' as "something dangerous or severe that happens suddenly or unexpectedly and needs rapid action to avoid harmful results", as per the Cambridge Dictionary (Emergency, n.d.). The UN Department of Humanitarian Affairs (1992, p. 34) also defines 'emergency' as "a sudden and usually unforeseen event that calls for immediate measures to minimize its adverse consequences". Both definitions encapsulate the concerns of environmental and youth organizations: the sense of urgency to act immediately and the consequences of not doing so. The etymological 
root of the word emergency emphasizes 'to arise' or 'to come to light.' Does the visibility of climate change impacts justify the use of the word emergency? Are they coming to light now? The writer Robert Macfarlane memorably wrote that the challenge with climate change is that its consequences may seep into everyday life without being noticed until the point at which the whole environment has been damaged beyond repair (see Macfarlane, 2005). On their side, the Alliance of World Scientists issued a warning in 2019 , asserting that the world was in a climate emergency and that mitigating and adapting to climate change would entail major transformations in our society (Ripple, Wolf, Newsome, Barnard, \& Moomaw, 2019). Although there is a perception of a growing frequency of impacts that would justify that emergency, there is also a sense that the crisis has been brewing over decades. Indeed, in the Declaration of the 1st World Climate Conference held by the World Meteorological Organization in 1979, it was agreed that it was urgently necessary for the nations of the world to foresee and prevent potential manmade [sic] climate changes and to develop a common global strategy for a greater understanding of the climate (World Meteorological Organization, 1979, p. 713). Hence, the climate emergency cannot be said to have arisen unexpectedly.

The adoption of an emergency frame in climate action may cause a need to question the political responses provoked by the declaration of emergency, as well as their effectiveness. Wilson and Orlove (2019) characterize a climate emergency by time pressure (which calls for immediate action and may forestall regular deliberations) and 'interval' (the space of time in which there is an opportunity to prevent disaster). As emergencies are socially constructed phenomena-open to contestation-they may be formulated for political gain or to justify action (through 'crisification'; Wilson \& Orlove, 2019). The emergency framing may produce a set of emotional and cognitive responses, which might shape decision making in unintended or even counterproductive ways.

The literature on the political consequences of emergency frames, in particular, demands caution in advancing emergency declarations. Emergencies often call for drastic action and a range of situations such as 'state of alert,' 'state of readiness,' 'state of internal war,' 'suspension of guarantees,' 'martial law' (Neocleus, 2006), or other extraordinary interventions (Wilson \& Orlove, 2019). Historically, the outbreak of an emergency has often led to declarations of a 'state of emergency' or 'state of exception,' that have justified harsh government interventions during periods of war, insurrection, or terrorist threat (Agamben, 2005; Fassin \& Pandolfi, 2010; Hulme, 2019). Consequently, some commentators fear that the impacts of climate change could trigger a new manifestation of the 'state of exception' in which new forms of authoritarianism become viable (Davies, 2019).

In this article, we follow the Copenhagen School's understanding of securitisation. Buzan, Wæver, and de Wilde (1998) defined securitisation as a 'speech act,' not interesting as a sign referring to something real, but the utterance itself constituting the act. At the same time, securitisation also depends on other components, such as the acceptance of securitisation by an audience or emergency action by agents. The securitisation of the environment is effective only when new institutions or strategies respond to specific securitisation objectives (Hughes, 2007; Matthew, 1999). These observations suggest that the emergency discourse has brought climate change beyond professional spheres of securitisation, into the public and social debate.

In terms of effectiveness, we need to understand the role of emergency discourses in contrast to other, more established, discourses of climate change action. In the lectures delivered by John Austin at Harvard University in 1955 (Austin, 1962), he proposed the existence of two kinds of utterances: 'constatives,' for conveying information, and 'performatives,' for performing actions. The notion of performatives captures how language utterances 'do things,' in addition to stating things (Austin, 1962). Austin's ideas connect what is being said and adopted (that there is a climate emergency) with what is being done (the consequences of declaring an emergency). Declaring a climate emergency entails an action because the action of 'declaring' compels city councils and other local actors to deliver climate change commitments. Climate declarations state motives and respond to those motives; however, the response can only be effective if concrete action emerges from such statements.

\section{Emergency Discourses and Local Action}

The novelty of cities' engagement with the climate emergency is questionable given that local governments have expressed their commitment towards environmental protection for decades. Municipal authorities had already been profiled as champions of sustainability in the UN-led program Agenda 21 (UN Division for Sustainable Development, 1992), which presented local governments as sensitive to public opinion, able to facilitate participation, and already in charge of planning and policymaking in multiple sustainability domains (e.g., Brugmann, 1996; Mehta, 1996). Initiatives established in the 1990s, such as the Cities for Climate Protection program led by the International Council for Local Environmental Initiatives (ICLEI), firmly located the climate mitigation agenda within the jurisdiction of local governments (Betsill, 2001; Bulkeley, 2000). There were many reasons why municipal authorities took an interest in emission reductions, including opportunities for win-win action due to energy conservation lowering costs and providing economic benefits (Bulkeley, 2000).

A broad range of 'co-benefits' associated with climate action at the city level has since then materialized, as emission reductions have been linked to a diversity of sectors and policy strategies (de Oliveira, 2013; 
Doll \& de Oliveira, 2017; Lee \& van de Meene, 2013; Rashidi, Stadelmann, \& Patt, 2017). Examples include job creation (e.g., through local contracting and new business opportunities linked with energy efficiency improvements; Betsill, 2001) as well as improved air quality and reduced congestion (e.g., through investment in public transport; Betsill, 2001; Thambiran \& Diab, 2011). In the last decades, nature-based solutions-responses that emphasise nature's role in providing environmental services-have become the dominant discourse of local climate action (Frantzeskaki et al., 2019). Climate mitigation has also increasingly become linked with established city branding strategies coupled with economic growth and investment through the association between low carbon development and a set of economic development aspirations, such as smart city and eco-city labels (Caprotti, 2014; Hollands, 2015; Long \& Rice, 2019).

Emergency declarations at the local level thus relate to existing trajectories of climate action and urban resilience concerns. Lack of action following the declaration of climate emergency can harm local governments' credibility. For government institutions, credibility depends on achieving consistency between words and deeds (Kouzes \& Posner, 2011; Lewicki \& Bunker, 1996; Shapiro, Sheppard, \& Cheraskin, 1992). Whatever their role, political leaders or social activists must act in ways consistent with the values of the people they represent (Kouzes \& Posner, 2011). Deficits in political legitimacy may emerge if credible action plans and forceful implementation do not match emergency declarations.

Further, nobody can predict the consequences and appropriations of an utterance, such as a climate emergency declaration. Derrida (1988) argued that if an utterance is performable, it can also be distorted, reused, misused, misperformed, changed, and twisted in some new way (Robinson, 2003). For Derrida, there was a danger in the opportunities to reimagine language and its performativity in different contexts. Austin and Searle suggested that utterances adopted outside their proper contexts may become 'parasite speech acts' because they 'act' but in ways in which they cannot be taken as serious or literal (Austin, 1962). Parasitic speech acts are different from normal speech acts because of the lack of alignment between motivations and the utterance-and its consequences (Halion, 1989). Utterances can also be parasitic if they pose a danger to the context in which they are pronounced.

Appropriations happen in every utterance. The constant use of the phrase 'climate emergency' distorts its meaning within climate change debates. The declarations themselves will constitute a problem if the lack of consistency between motivations and responses leads to a devaluation of emergency discourse, without an alternative to substitute it. Aside from promoting authoritarianism, as feared by some, subtler risks may be embedded in emergency declarations if they direct social efforts for collective action in ways that do not promote the overall public good. Indeed, the declaration of climate emergencies has received criticism for being too narrow when positioning climate change against other pressing issues (e.g., poverty, economic and social inequality), and for expressing a new form of a democratic 'green populism' (Davies, 2019; Hulme, 2019).

The climate emergency declarations appear to have created momentum for climate action and galvanised a social movement. They may have opened spaces for collaboration within the geographies in which they have been declared. However, there is considerable uncertainty about their role and potential. We propose to examine the motivations and intended outcomes embedded in local governments' emergency declarations as a first step towards exploring their role in local governance.

\section{Methodology}

Cedamia.org (derived from "Climate Emergency Declaration and Mobilisation in Action") is a campaign to promote climate emergency declarations at all levels of government, in partnership with the Council Action in the Climate Emergency (CACE). Margaret Hender and Philip Sutton manage a website and a Facebook group that provide access to available declarations. We selected 300 declarations from local governments available from this archive (Supplementary File 1) which, in total, cover a population of over 85.6 million people. To identify declarations for analysis, we selected all declarations (148 in total) from countries that had issued less than 25 declarations (from countries with only two declarations, such as Brazil and Sweden, to those with up to 25 declarations, such as Germany). Next, we selected 152 documents from the six countries with more than 25 declarations adopted by cities with more than 50,000 people. When the information on the declaration contained in the archive was limited to simply the acknowledgement of a declaration having been made, we resorted to additional documents to obtain information on the motivations and intended outcomes of the emergency declaration. Those additional documents included press articles available for cities that reported the declaration's adoption, the minutes from the public meetings that led to the declaration, and public statements or interviews discussing their importance. We analysed the original declarations in English, Swedish, French, Italian, and Spanish. For any other languages, we used translated versions.

We compared the declarations in an excel spreadsheet, which allowed for systematic comparison and evaluation of patterns across cases. The 300 declarations were coded according to a set of pre-defined categories for motivations and intended outcomes. It is important to note that many declarations include multiple motivations behind their adoption (while some did not provide any motivation). As a result, the sum of $\mathrm{N}$ is greater than 300. Each co-author coded 100 declarations, followed by a revision of each others' coding. Tables 1 and 2 provide 
an overview of the themes and their frequencies. For motivations, we also compiled a table exemplifying the topics with quote examples (Supplementary File 2).

\section{Motivations to Adopt Climate Declarations}

Our analysis of the motivations behind the declarations shows that local governments operate in the interface between international discourse and place-based concerns. There are various mechanisms at play, which we have grouped into three sets of rationales: political positioning, articulation of local concerns, and pressure from the civil society (Table 1 ). While most cities cited multiple reasons behind the adoption, $15 \%$ of authorities in our sample did not explain their rationale at all.

The first set of motivations relate to political positioning and international signalling of climate action intentions. A third of the declarations presented such motivation with reference to international policy (for example, references to the Paris Agreement and the SDGs, international events such as the Rio Summit or the COP conferences, or regulatory instruments such as the Kyoto Protocol and EU directives). Many declarations explicitly mention IPCC reports, mainly the target to keep global average temperature changes under $1.5^{\circ} \mathrm{C}$. These motivations were similarly phrased across municipalities (especially declarations within the same country, such as Belgium), suggesting that local governments shared templates. These similarities suggest that the declarations do not necessarily reflect local knowledge of international politics.

A different political positioning style is visible concerning other government institutions within the sphere of influence of a particular local government. Many declarations ( $14 \%$ of declarations) were adopted following the declaration of emergency in other local governments within a given regional or national context. Positioning local government in relation to higher government levels was also common ( $10 \%$ of declarations). Declarations are presented as advocacy exercises to demand the transfer of funds, respond to higher-level resolutions, or highlight federal and state governments' lack of action. A final political justification was to respond to local party politics (6\% of declarations). For example, many German cities declared a climate emergency following the request of Fridays for Future, which was supported by the Green Party and the Social Democratic Party. The same occurred in cities in Belgium and Spain, where the greens tabled motions to pass declarations. In some cities, opposition groups proposed the declaration as a strategy to obtain political visibility. Here, the political environment was an essential factor, as green and leftgreen parties played a central role in many cases.

The second set of motivations relates to specific conditions associated with climate change. The most common was a history of local government commitment to sustainability and identity of environmental leadership (e.g., commitments to emission reductions, carbon neutral targets, and participation in transnational networks; $24 \%$ of declarations). For instance, the Declaration of Recife (Brazil) mentioned that their Mayor is the president of ICLEI South America. Tacoma (US) located the declaration within its history as one of the US's most contaminated sites, which has inspired decades of environmental engagement. This rhetoric echoes Agenda 21 discourses, viewing local government-the authority closest to the people-as holding special responsibility to advance sustainability and protect future generations. Many of these justifications communicate an unmistakable sense of pride in the city's trajectory of environmental action. Links with social issues also emerged, such as precariousness and social exclusion, fuel poverty, and impacts on the homeless (6\% of declarations). Many cities in France associated the declaration with the yellow vest protests against rising fuel prices.

Motivations related to local conditions also included the experience of climate impacts ( $9 \%$ of declarations). In Australia, for example, the declarations referred to stress on water resources and the death of animals,

Table 1. Summary of motivations to declare a climate emergency (Supplementary File 2).

\begin{tabular}{llrr}
\hline Motivation behind adoption & & N & Frequency \\
\hline None & No explicit rationale & 46 & 0.15 \\
Political positioning & International policy & 100 & 0.33 \\
& Following other cities & 44 & 0.14 \\
& Positioning vis-a-vis higher-level government & 29 & 0.10 \\
& Party politics & 19 & 0.06 \\
Local concerns & History of environmental commitment & 31 & 0.24 \\
& Awareness of climate risks & 32 & 0.11 \\
& Previous impacts & 28 & 0.09 \\
Pressure from civil society & Link to social concerns & 16 & 0.06 \\
& Pressure from citizen and environmental groups & 65 & 35 \\
& Pressure from a single NGO & 27 & 0.22 \\
\hline
\end{tabular}


storms, floods, and fires. A similar rationale was the awareness of current and future risks ( $11 \%$ of declarations). For instance, Prague's declaration was adopted after an investigation that demonstrated links between heat and the absence of green space. Other declarations pointed to future risks of heat exposure, flooding, sea-level rise, storm surges, and increased risk of disease. Some declarations referred to regional conditions, such as the vulnerability of the Mediterranean in cities in Spain and France, or, in several Japanese declarations, the prevalence of typhoons.

The third set of motivations followed pressure from civil society. Many declarations referred to citizens' petitions or the combined pressure from protests and the demands of local groups (22\% of declarations). The largest number of such motivations were in Canada, where NGOs and activists exerted pressure through petitions, participation at council meetings, and protests. There were instances where a history of environmental activism and conflict was a strong influence, such as in Hualpén in Chile. The recurrent mentions of some environmental groups in the declarations suggest that those groups have influenced public discourses, such as Rise for Climate in Belgium, Extinction Rebellion in the UK and New Zealand, People Before Profit in Ireland, and Fridays for the Future in Germany and Italy.

What is the relationship between these motivations and the act of declaring an emergency? First, the reasons to declare an emergency rarely describe a newly emerged, urgent challenge; that is, something dangerous or serious that happens suddenly or unexpectedly. About $9 \%$ find motivation in recent climate changerelated impacts, but, for most, the justification builds on science, international policy, and global, rather than local, urgency. Second, while only some declarations contain an explicit call for action, many consolidate and showcase environmental commitment trajectories, where climate change is rarely seen as a new, unexpected event. Continuity (long-term action) rather than sudden responses appear to be more central to emergency declarations (Wilson \& Orlove, 2019). The performative element of the emergency declarations consists of modelling examples of climate action and increasing social mobilization momentum, rather than fostering action in the specific locales where the declarations are adopted.

\section{Intended Outcomes of Emergency Declarations}

The arguments in terms of the intended outcomes of the declarations are polarised. On one extreme, declarations are criticised as mere forms of signification, political moves with little more than symbolic value. Some politicians openly express that they are meeting public demands without committing to anything in particular. For example, in Villingen-Schwenningen (Germany) officials proposed that committing to the declaration 'would not hurt.' On the other extreme, the declarations consti- tute a commitment to action, connected to precise and specific demands from societal groups and the start of a path towards practical action for local governments, as exemplified for example, in the presentation of declarations in Irish municipalities as heralding a new way of doing climate politics aligning climate change and biodiversity concerns. The reality is usually something in between. Declarations result from both elements, the symbolic and the practical because both symbolic and practical elements are intimately linked in a performative utterance of this kind. Accordingly, most declarations provided evidence of both.

Table 2 presents an overview of the intended outcomes identified in the sample of declarations reviewed. A variety of intentions to achieve impact are embedded in the declarations. 52 declarations could not be linked to intended outcomes (17\%). Almost half of the declarations (46\%) show 'aspirational outcomes,' that is, intended outcomes in terms of the conception of the local government as an active agent in climate change action, the need to show leadership, and the embedded belief that this is a moment to 'change minds.' Some of the strategies repeated across declarations show a deliberate alignment of the declaration with ongoing strategies to deliver sustainability. For example, some declarations are aligned with concerns about other environmental issues, such as waste management in Japan. In countries like Ireland and Italy, the declarations emphasize the consideration of the climate emergency with a parallel biodiversity emergency, as reflected in the Intergovernmental Science-Policy Platform on Biodiversity and Ecosystem Services (IPBES) report. Statements of specific targets were less frequent. Many local governments aligned themselves with targets at higher governance levels, but $9 \%$ of the declarations established specific targets for their city. The action of setting a target establishes a benchmark for accountability alongside a direction for the action. Some of the declarations (11\%) set explicit environmental education objectives.

A third of the declarations proposed specific actions to shape ongoing governance processes. For example, $19 \%$ of declarations promised to undertake planning activities, such as a Climate Action Plan or the deliberate integration of climate change-related measures in ongoing efforts at Masterplanning or Transport Planning. About $9 \%$ of the declarations stated that local government operations would mainstream climate change, for example, using climate impact assessments for any new developments and policies. Very few (10 declarations out of 300) made provisions for mobilizing economic and financial resources for climate action, whether through finance, making an explicit request to other government levels, or committing a part of the existing budget.

A quarter of the declarations position the local government as a central actor providing coordination or climate change action leadership. $13 \%$ of the declarations are explicit about the local government's role to nudge other government levels to take action. Many declara- 
Table 2. Summary of intended outcomes of declaring a climate emergency.

\begin{tabular}{lrr}
\hline Intended outcomes of the declaration & N & Frequency \\
\hline Aspirational objectives & 139 & 0.46 \\
$\quad$ Aligning declaration to ongoing strategies & 79 & 0.26 \\
$\quad$ Environmental education for citizens & 34 & 0.11 \\
$\quad$ Setting specific targets & 161 & 0.09 \\
No clear aspirational outcomes & 95 & 0.54 \\
Direct impact on existing governance processes & 28 & 0.32 \\
$\quad$ Integration of climate change into impact assessments & 10 & 0.09 \\
$\quad$ Mobilization of economic resources & 57 & 0.03 \\
Planning (from Transport Planning to Masterplanning) & 205 & 0.19 \\
No practical outcomes & 75 & 0.68 \\
Coordination with other actors & 36 & 0.25 \\
$\quad$ Multi-level dialogue & 39 & 0.12 \\
Nudge other government levels into action & 225 & 0.13 \\
No multi-level changes & 32 & 0.75 \\
Restrictions on further action & 25 & 7 \\
$\quad$ Create new municipal or other institutions, e.g., working group or committee & 20 & 0.11 \\
Move away from fossil fuels & 0.08 \\
Restrict future municipal decisions & 0.07 \\
\hline
\end{tabular}

tions identify the institution to be reached and the channels of communication to make it possible. The declarations are themselves part of that nudge. About $12 \%$ of the declarations focus on creating a multi-level dialogue to build forms of horizontal governance, bringing together communities, enabling participatory processes, or enabling civil society actors to act for climate change.

Finally, just over $11 \%$ of the declarations contain explicit attempts restricting future action. Of those, $8 \%$ commit local governments to create a specific body to deal with the climate emergency, be it a dedicated committee within the local government or a multi-actor conference. Also, $7 \%$ of the declarations pledge to enshrine climate change in local government operation frameworks so that climate concerns will influence and restrict future council decisions. Finally, a few declarations commit to divestment on fossil fuels (only 7 out of 300).

The analysis above shows that the declarations are themselves performative by proposing policy changes that align the operation of local government with its stated motivations; the integration of climate change in planning and impact assessment; the mediation of multi-level dialogues across government, civil society, and business; and the construction of a coherent message to influence governance futures. The declarations also shape what a climate emergency is and how to approach it. Rather than providing a sense of urgency in climate responses, the declarations emphasize the need to change climate politics by situating local governments as crucial agents bridging global and local action agendas. 'Less haste, more speed' is the motto of a report from Arup on how local governments can respond to the climate emergency (Arup, 2019). This report's key message is that addressing the climate emergency entails redefin- ing local governance. Redefining local governance seems to be the main purpose of local emergencies, although the extent to which this has happened is unclear.

\section{Conclusions}

Emergency declarations can be read as positioning exercises without a real impact on climate change motivations and stressors. However, our analysis also suggests that there are good reasons to be optimistic about them: They have a performative component that manifests both in the motivations for making them and their intended outcomes. Such declarations have multiple effects, from modelling environmental action trajectories to fostering multi-level dialogues. They anticipate practical effects in changing local governance, from shaping planning and making future commitments to setting targets, although evidence of those changes is not available in this assessment.

The adoption of the declarations shows the limited geography of a 'climate declarations movement' related to the emergency discourse, as most declarations were adopted in six countries: the UK (with $44 \%$ of the declarations), Australia, Germany, Canada, USA, and Italy (with 67 declarations). Accordingly, the declarations' motivations emphasize questions of responsibility instead of questions of risk and security and leave drivers of structural vulnerability untouched. The analysis of motivations suggests that proximity was an important factor in adopting declarations, whether because other local governments acted as models or because they were exposed to similar pressures. The declarations appear as a collective event rather than multiple instances that should be looked at in isolation. 
Are climate emergency declarations, then, 'constative' or 'performative'? In consideration of Austin's (1962) reflections, local governments can adopt a climate emergency to allow the constative (the statement of declaring the emergency) to function performatively (the mere fact of adopting the emergency constitutes an action). If the declaration absolves further intervention, it would be counterproductive to support local climate action. Suppose the adoption of the emergency declarations in themselves is seen as constituting decisive action (suggesting that no further measures are required once the declaration is adopted). In that case, it could be directly detrimental to making progress in climate protection at the local level. The declarations prefigure action to move local governments to change some practices, but they hardly envisage transformative actions. As explained above, only $11 \%$ of declarations foray into institutional change, for example, restricting municipal decisions or facilitating divesting. None of those offer examples of undemocratic, authoritarian action advanced under the discourse of emergency. In line with this, the declarations do not demonstrate that climate change is being successfully securitised in these countries. Declaring a climate emergency is not evidence of securitisation, particularly without evidence of action by agents within the securitisation industry (Warner \& Boas, 2017). Our findings do not confirm that securitisation follows public declarations of climate emergency, in town hall meetings, or with climate activists' participation. Rather a successful climatization seems to be observed in spheres of economic policy, in military investments, or in the changes of discourses in the security industry that hardly intervene in the emergency declarations at the local level (Oels, 2012).

Our research suggests that local climate politics have been changed by adopting emergency declarations at the local level. The collective stand of 1,500 local government authorities from around the world, at the very least, signals a spirit of solidarity and unity that may support further action and ambition. It shows the role cities are willing to play at the international level to give answers to global challenges and respond to the demands of an increasingly aware society. The declarations have been an opportunity to renew the cities' compromises in the fight against climate change and to deal with the clear demands of a part of the population that were seeking greater engagement at the local level. As Hulme (2019) reminds us, once a climate emergency is declared, it is hard to see how it can be undeclared; the question then becomes how will cities deliver their promises and how will it impact their credibility. In this sense, the emergency declarations may be performative by producing enduring alliances and lasting perceptions of what it means to live in a society under threat of climate change. At the same time, the research also indicates that most cities have not adopted plans or initiatives that go much further than those that were already planned and that the declaration of emergency does not differ much in terms of plans to reduce emissions or adapt to climate change at the local level.

What we found absent in the climate emergency declarations examined was the question of urgency. The declarations recast climate change urgency as a call for shaping climate change governance, rather than rushing into delivering hasty or ill-conceived measures. From collaborative governance approaches to public consultations and legitimacy-building measures, the declarations herald a different era in climate change politics at the local level. Rather than driving local governments towards a state of exception-opening the door for authoritarian politics-the declarations constitute an anchor to dialogue across local government, social movements, and the private sector. In the context of increasing political polarization, the declarations establish bridges for dialogue at the local level. Bridges are also visible in the growing movements for climate justice, which emphasize the impacts of transitions on disadvantaged groups.

In summary, the emergency declarations are neither effective in creating a new age of climate action at the local level nor are they as dangerous as securitisation scholars suggest. While the emergency declarations seemed to have captured a particular moment of social concern regarding climate change, they follow a long trajectory of climate action at the local level. Maintaining the momentum seems to be the name of the game.

\section{Acknowledgments}

This article is an output of the project LO-ACT (Low Carbon Action in Ordinary Cities), funded by the European Research Council (ERC) under the European Union's Horizon 2020 research and innovation programme (Grant Agreement No 804051-LO-ACT-ERC-2018-STG).

\section{Conflict of Interests}

The authors declare no conflict of interests.

\section{Supplementary Material}

Supplementary material for this article is available online in the format provided by the author (unedited).

\section{References}

Agamben, G. (2005). A brief history of the state of exception by Giorgio Agamben: An excerpt from state of exception. University of Chicago Press. Retrieved from https://press.uchicago.edu/Misc/ Chicago/009254.html

Anderson, B., \& Adey, P. (2012). Governing events and life: "Emergency" in UK civil contingencies. Political Geography, 31(1), 24-33.

Arup. (2019). You've declared a climate emergency... what next? London: Arup. 
Austin, J. L. (1962). How to do things with words: The William James lectures delivered at Harvard University in 1955. Oxford: Oxford University Press.

Barnett, J., \& Adger, W. N. (2007). Climate change, human security and violent conflict. Political Geography, 26(6), 639-655.

Betsill, M. M. (2001). Mitigating climate change in US cities: Opportunities and obstacles. Local Environment, 6(4), 393-406.

Brown, C., Brown, E., Murray-Rust, D., Cojocaru, G., Savin, C., \& Rounsevell, M. (2015). Analysing uncertainties in climate change impact assessment across sectors and scenarios. Climatic Change, 128, 293-306.

Brugmann, J. (1996). Planning for sustainability at the local government level. Environmental Impact Assessment Review, 16(4/5/6), 363-379.

Bulkeley, H. (2000). Down to Earth: Local government and greenhouse policy in Australia. Australian Geographer, 31(3), 289-308.

Bulkeley, H., \& Kern, K. (2006). Local government and the governing of climate change in Germany and the UK. Urban Studies, 43(12), 2237-2259.

Buzan, B., Wæver, O., \& de Wilde, J. (1998). Security: A new framework for analysis. London: Lynne Rienner Publishers.

Caprotti, F. (2014). Critical research on eco-cities? A walk through the Sino-Singapore Tianjin eco-city, China. Cities, 36, 10-17.

Cedamia. (2020). Climate emergency declaration evolution. Cedamia. Retrieved from https://www. cedamia.org/news/climate-emergency-declarationevolution

Committee OTEOC. (2011). Climate change, the indoor environment, and health. Washington, DC: National Academies Press.

Davies, W. (2019). Green populism? Action and mortality in the anthropocene. CUSP. Retrieved from https:// www.cusp.ac.uk/themes/m/m1-12

de Oliveira, J. A. P. (2013). Learning how to align climate, environmental and development objectives in cities: Lessons from the implementation of climate co-benefits initiatives in urban Asia. Journal of Cleaner Production, 58, 7-14.

Derrida, J. (1988). Limited inc. Evanston, IL: Northwestern University Press.

Diaz, J. (2004). The public health impact of global climate change. Family Community Health, 27(3), 218-229.

Dinar, A., Mendelsohn, R., Evenson, R., Parkh, J., Sanghi, A., Kumar, K., . . . Lonergan, S. (1998). Measuring the impact of climate change on Indian agriculture (World Bank technical paper no. WTP 402). Washington, DC: The World Bank.

Doll, C. N., \& de Oliveira, J. A. P. (2017). Urbanization and climate co-benefits: Implementation of win-win interventions in cities. Abingdon: Taylor \& Francis.

Emergency. (n.d.). In Cambridge dictionary. Retrieved from https://dictionary.cambridge.org/es/ diccionario/ingles/emergency
Fassin, D., \& Pandolfi, M. (2010). Contemporary states of exception. New York, NY: Zone Books.

Frantzeskaki, N., McPhearson, T., Collier, M. J., Kendal, D., Bulkeley, H., Dumitru, A., . . . Pintér, L. (2019). Naturebased solutions for urban climate change adaptation: Linking science, policy, and practice communities for evidence-based decision-making. BioScience, 69(6), 455-466.

Giles Carnero, R. (2016). El cambio climático como riesgo y amenaza para la seguridad: derivaciones en el desarrollo del régimen jurídico internacional en materia de clima [Climate change as risk and security threat: Implications for the evolution of the international climate change regime]. Araucaria, 18(36), 315-338.

Goodwin, T., Thronton, C., Proffitt, R., Bender, A., Seal, S., \& Corley, A. (2017). Climate change-related water disasters' impact on population health. Journal of Nursing Scholarship, 49(6), 625-634.

Halion, K. (1989). Speech act theory and deconstruction: A defence of the distinction between normal and parasitic speech acts. e-Anglais. Retrieved from https:// www.e-anglais.com/thesis.html

Harvey, F. (2020, December 12). UN secretary-general urges all countries to declare climate emergencies. The Guardian. Retrieved from https://www. theguardian.com/environment/2020/dec/12/unsecretary-general-all-countries-declare-climateemergencies-antonio-guterres-climate-ambitionsummit

Hollands, R. G. (2015). Critical interventions into the corporate smart city. Cambridge Journal of Regions, Economy and Society, 8(1), 61-77.

Hughes, H. (2007). Climate change and securitization (Unpublished Master's thesis). Cambridge University, Cambridge, UK.

Hulme, M. (2019). Climate emergency politics is dangerous. Issues in Science and Technology, 36(1), 23-25.

Intergovernmental Panel on Climate Change. (2014). Climate change 2014: Synthesis report-Contribution of working groups I, II and III to the fifth assessment report of the Intergovernmental Panel on Climate Change. Geneva: Intergovernmental Panel on Climate Change.

Jaeschke, A., Bittner, T., Jentsch, A., \& Beierkuhnlein, C. (2014). The last decade in ecological climate change impact research: Where are we now? Naturwissenschaften, 101, 1-9.

Jayaram, D. (2020). 'Climatizing' military strategy? A case study of the Indian armed forces. International Politics, 2020. Retrieved from https://link.springer.com/ article/10.1057/s41311-020-00247-3\#citeas

Kahn, M., Mohaddes, K., Ng, R., Hashem, M., Raissi, M., \& Yang, J. (2019). Long-term macroeconomic effects of climate change: A cross-country analysis (IMF Working Paper WP/19/215). Washington, DC: International Monetary Fund.

Kern, K., \& Alber, G. (2009). Governing climate change in 
cities: Modes of urban climate governance in multilevel systems. In Proceedings of the OECD Conference on Competitive Cities and Climate Change (pp. 171-196). Paris: OECD.

Kouzes, J., \& Posner, B. (2011). Credibility: How leaders gain and lose it, why people demand it. San Francisco, CA: Jossey-Bass.

Lee, T., \& van de Meene, S. (2013). Comparative studies of urban climate co-benefits in Asian cities: An analysis of relationships between $\mathrm{CO}_{2}$ emissions and environmental indicators. Journal of Cleaner Production, 58, 15-24.

Lewicki, R., \& Bunker, B. (1996). Developing and maintaining trust in work relationships. In R. Kramer \& T. Tyler (Eds.) Trust in organisations: Frontiers of theory and research (pp. 114-139). Thousand Oaks, CA: Sage.

Long, J., \& Rice, J. L. (2019). From sustainable urbanism to climate urbanism. Urban Studies, 56(5), 992-1008.

Macfarlane, R. (2005, September 24). The burning question. The Guardian. Retrieved from https:// www.theguardian.com/books/2005/sep/24/ featuresreviews.guardianreview29

Madhusoodhanan, C. G., Sreeja, K. G., \& Eldho, T. I. (2016). Climate change impact assessments on the water resources on India under extensive human intervention. Ambio, 45(6), 725-741.

Maharjan, L., \& Joshi, J. (2013). Climate change, agriculture and rural livelihoods in developing countries. Berlin: Springer.

Matthew, R. A. (1999). Introduction: Mapping contested grounds. In D. H. Deudney \& R. A. Matthew (Eds.), Contested grounds: Security and conflict in the new environmental politics (pp. 1-22). Albany, NY: SUNY Press.

Matthew, R. A. (2000). The environment as a national security issue. Journal of Policy History, 12(1), 101-122.

Mehta, P. (1996). Local agenda 21: Practical experiences and emerging issues from the South. Environmental Impact Assessment Review, 16(4/5/6), 309-320.

Neocleus, M. (2006). The problem with normality: Taking exception to "permanent emergency." Alternatives, 31(2), 191-213.

Oels, A. (2012). From 'securitization' of climate change to 'climatization 'of the security field: Comparing three theoretical perspectives. In J. Scheffran, M. Brzoska, H. Brauch, P. Link, \& J. Schilling (Eds.), Climate change, human security and violent conflict (pp. 185-205). Berlin and Heidelberg: Springer.

Rashidi, K., Stadelmann, M., \& Patt, A. (2017). Valuing co-benefits to make low-carbon investments in cities bankable: The case of waste and transportation projects. Sustainable Cities and Society, 34, 69-78.

Reid, H., Linda, S., Stage, J., \& Macgregor, J. (2008). Climate change impacts on Namibia's natural resources and economy. Climate Policy, 8(4), 452-466.

Ripple, W. J., Wolf, C., Newsome, T. M., Barnard, P., \&
Moomaw, W. R. (2019). World scientists' warning of a climate emergency. BioScience, 70(1), 8-12.

Robinson, D. (2003). Performative linguistics: Speaking and translating as doing things with words. London: Routledge.

Scott, S. V. (2012). The securitisation of climate change in world politics: How close have we come and would full securitisation enhance the efficacy of global climate change policy? Review of European Community \& International Environmental Law, 21(3), 220-230.

Shapiro, D., Sheppard, B., \& Cheraskin, L. (1992). Business on a handshake. Negotiation Journal, 8(4), 365-377.

Spratt, D., \& Sutton, P. (2008). Climate code red: The case for emergency action. Melbourne: Scribe.

Stern, N. (2007). The economics of climate change: The Stern review. London: HM Treasury.

Thackeray, S. J., Robinson, S., Smith, P., Rhea, B., Bernacchi, C., Byrne, M., . . . Long, S. (2020). Civil disobedience movements such as school strike for the climate are raising public awareness of the climate change emergency. Global Change Biology, 26(3), 1046-1044.

Thambiran, T., \& Diab, R. D. (2011). Air pollution and climate change co-benefit opportunities in the road transportation sector in Durban, South Africa. Atmospheric Environment, 45(16), 2683-2689.

Thomas, K. A., \& Warner, B. P. (2019). Weaponizing vulnerability to climate change. Global Environmental Change, 57. https://doi.org/10.1016/j.gloenvcha. 2019.101928

Torres Camprubí, A. (2016). Securitization of climate change: The inter-regional institutional voyage. Yearbook of International Environmental Law, 27(1), 82-105.

UN. (1992). United Nations conference on environment \& development: Agenda 21. New York, NY: UN Division for Sustainable Development. Retrieved from https://sustainabledevelopment.un.org/content/ documents/Agenda21.pdf

UN chief makes Antarctica visit. (2007, November 10). BBC. Retrieved from http://news.bbc.co.uk/2/ hi/science/nature/7088435.stm

UN Department of Humanitarian Affairs. (1992). Internationally agreed glossary of basic terms related to disaster management. Geneva: UN Department of Humanitarian Affairs. Retrieved from https:// reliefweb.int/sites/reliefweb.int/files/resources/ 004DFD3E15B69A67C1256C4C006225C2-dhaglossary-1992.pdf

UN Environment Programme. (2019, July 10). Higher and further education institutions across the globe declare climate emergency [Press release]. Retrieved from https://www.unenvironment.org/news-andstories/press-release/higher-and-further-educationinstitutions-across-globe-declare

Wade, K., \& Jennings, M. (2016). The impact of climate change on the global economy. London: Schroders. 
Retrieved from https://www.schroders.com/de/

SysGlobalAssets/digital/us/pdfs/the-impact-of-

climate-change.pdf

Wang, J., Menderlsohn, R., Dinar, A., Huang, J., Rozelle, S., \& Zhang, L. (2009). The impact of climate change on China's China's agriculture. Agricultural Economics, 40(3), 323-337.

Warner, J., \& Boas, I. (2017). Securitisation of climate change: The risk of exaggeration. Ambiente \& Sociedade, 20(3), 203-224.

Wilson, A. J., \& Orlove, B. (2019). What do we mean when we say climate change is urgent? (Center for Research on Environmental Decisions Working Paper 1). New York, NY: Center for Research on Environmental Decisions. Retrieved from https:// academiccommons.columbia.edu/doi/10.7916/d8b7cd-4136

World Meteorological Organization. (1979). Proceedings of the world climate conference: Geneva, 1223 February 1979. Geneva: World Meteorological Organization.

\section{About the Authors}

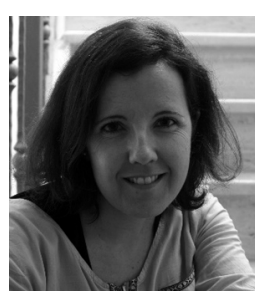

Xira Ruiz-Campillo is a Professor of International Relations at the Faculty of Political and Social Sciences of the Complutense University of Madrid (UCM). She holds a PhD in International Relations at the UCM. Prior to joining the university, she worked at UNHCR and the Spanish Ministry of Defence as an Analyst. She has previously published in the fields of European climate leadership and crisis management. Currently, her research focuses on the role of cities as international actors.

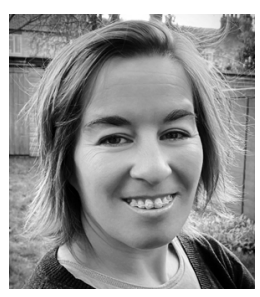

Vanesa Castán Broto is a Professor of Climate Urbanism at the Urban Institute at the University of Sheffield. She is the recipient of a European Research Council Starting Grant for the project Low Carbon Action in Ordinary Cities (LO-ACT). She also leads the international consortium CESET, studying community energy in East Africa from a feminist standpoint. Her last books include the monographs Urban Energy Landscapes (2019, Cambridge University Press) and Urban Sustainability and Justice (co-authored with Linda Westman, 2019, ZED Books).

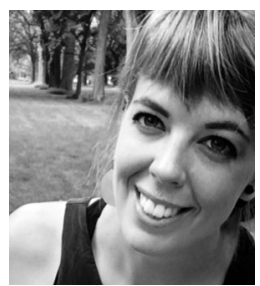

Linda Westman is a Research Associate at the Urban Institute of the University of Sheffield whose work engages with governance and justice dimensions of sustainability and climate change. She currently manages a work package of the ERC-funded project LO-ACT, which examines climate action in 'ordinary' cities. Her previous publications engage with climate governance in China and the role of the private sector in urban sustainability transformations. 